\title{
Pre Sowing Seed Treatments of Magnetic, Electric, Polyethylene Glycol, Sodium Chloride on Seedling Parameters of Desi Chickpea (Cicer Arietinum L.)
}

\author{
Rupesh Kumar*and Prashant Kumar Rai \\ Department of Genetics and Plant Breeding, Sam Higginbottom University of Agriculture, \\ Technology and Sciences, Prayagraj-211007, Uttar Pradesh, India \\ *Corresponding author
}

\begin{tabular}{|l|}
\hline Ke y w o r d s \\
Chickpea (DCP-92- \\
3), pre sowing seed \\
treatment, \\
polythene bag, \\
seedling \\
parameters.
\end{tabular}

This present study was elucidated the effects of different pre sowing seed treatments on stored seeds of Desi Chickpea seeds. Seeds were stored in plastic bags for one planting season, i.e. 8 months under ambient and control conditions of Prayagraj. After storage, seeds were treated with different doses of Polyethylene Glycol 6000, sodium chloride, magnetic and electric seed treatments. Observations showed that the seeds stored in plastic bags for eight months ageing treatments displayed that the seedling parameters were also found more affected in Polyethylene Glycol as compared to sodium chloride, magnetic and electric seed treatments. Germination and vigour percentage decreased with the period of ageing. Seeds of Chickpea (DCP-92) are stored in plastic bags were affected due to storage but the effects were more pronounced in PEG 6000 as compared to other treatments.

\section{Introduction}

Chickpea is the third most important food legume crop and is grown in several countries worldwide as a food source. Seed is the main edible part of the plant and is a rich source of protein, carbohydrates and minerals especially for the vegetarian population. As in case of other legume crops, even chickpea can fix atmospheric nitrogen through its symbiotic association with Rhizobium sp.; thus helping in enhancing the soil quality for subsequent cereal crop cultivation. Even though India is the largest producer of chickpea; it still imports chickpea from other countries. Keeping in view, the ever-increasing demand for this legume crop; it is essential to improve the production and area under cultivation, at the same time minimizing the stress on this crop plant. Two types of chickpeas are recognized, the white-seeded "Kabuli" and the brown colored "Desi" types. Kabuli chickpeas are relatively bigger in size having a thinner seed coat while the Desi type seeds are relatively smaller in size having a thicker seed coat. The Desi type chickpea contributes to around $80 \%$ and the Kabuli type around $20 \%$ of the total production. 
Packaging is an important part of product processing and preservation and has direct influence on the system in respect to physical and chemical changes. The packaging materials used are decided by kind and quantity of seed to be packed, the type of package, duration of storage, storage temperature and relative humidity of the storage area, etc. The farmers practice of storing crop seeds in gunny bag as well as in cloth bags hastens up the seeds quality deterioration process, thus resulting in poor seed quality. The use of high density polythene bag packaging materials in seeds storage were found to retain the quality, but for a limited period.

In agriculture, seed is a vehicle to deliver almost all agro based technological innovations so that the farmers can exploit the genetic potential of new varieties. Ageing is an universal physiological phenomenon occurring in living organisms. It is one of the most intriguing and challenging scientific problems of universal concern. The poor seed storability is a major problem in chickpea. The changes associated with seed deterioration are manifested in various seed and seedling characters at different stages. Among these deteriorative changes, membrane degradation has been proposed as the primary event in ageing (Rai et al, 2011).

Seed treatments have played and are still playing a pivotal role in sustainable crop production which is also evidenced from the history of mankind. Seed treatments have helped to improve the yields of many different crops by providing the protection from pre and post-emergent insects and diseases and insurance of a uniform stand across a wide variety of soil types, cultural practices and environmental conditions. Seed treatments provide an economical crop input that is applied directly on the seed using highly effective technology. Seed priming is a technique controlling hydration and drying, that results in more rapid germination when the seeds are re-imbibed. Seed priming technique has been found to be a feasible technology to improve seedling emergence in some field crops, such as cotton, common maize, rice and wheat. In Chickpea, seed priming commonly used to reduce the time between seed sowing and seedling emergence and to improve the percentage of emergence. The benefits of seed priming had been reported, including improving stand establishment in semi-arid condition and at drought stress, enhancing seed with low vigor, improving dormancy breakdown, or increasing productivity. The appropriate water holding capacity, consistency, and high porosity of peat moss are qualities that have contributed to its worldwide use as an ingredient of growing substrates and as a carrier for commercial bacterial inoculants.

Physical methods mainly include ultrasound treatment, plasma processing, electromagnetic field and static processing, magnetized water or temperature treatment, microwave processing etc. Enzyme activity, which is beneficial to transfer starch, protein or other substances into soluble matters that could be absorbed by embryos, can be improved by different methods of treating seeds and then it can enhance the seeds germination rate, promote seeds growth and increase the crop yield. However, the current methods have some shortcomings. Chemical agents may damage the seeds and thus have negative effects on the growth and development of crops due to the high residual medicine in seed. Moreover, the physical treatments, e.g. high pressure electrostatic processing, consume too much energy and have low safety coefficient. Thus, it is necessary to take a safe and low consumption method, electrochemical method, to treat the seeds. Seeds treatment using electrochemical method has great advantages, such as low energy consumption, normal temperature, atmospheric pressure; the system has strong electromagnetic field effect (Zhao et al. 2012).

Magnetic field may play an important role in cation uptake capacity and has a positive effect on immobile plant nutrient uptake. Studies on the meri-stematic cells of plants have shown that magnetic field effects normal metabolisms and has impact on cellular division. Magnetic fields affect the synthesis of DNA and RNA as well as the cellular proliferation (Rostami et al, 2014). Hence, present studies were undertaken to assess the effect of different pre sowing seed treatments on seedling parameters of Desi Chickpea (DCP-92-3) seeds under ambient and control conditions of Prayagraj. 


\section{Materials and Methods}

Chickpea (DCP-92-3) seeds were obtained from Indian Institute of Pulses Research (I.I.P.R), Kanpur. Seeds were stored in plastic bags for one planting season, i.e. 6 months under ambient and control conditions of the Post Graduate Laboratory, Department of Genetics and Plant Breeding, SHUATS, Prayagraj. The treated seeds and control seeds (fresh seeds) were grown in petridishes in Laboratory same day after storage with four replications. The petridishes were placed in incubator maintained at $25+10 \mathrm{C}$. For each treatment ten seeds were used in each replication. The seeds from each sample were then germinated on moist filter paper in petridishes.

For seedling characters, the germination test was conducted using four replications of 100 seeds from each sample in petridish as per procedure described by ISTA (2010). Seedling dry weight and vigour index I and II were determined by Baki and Anderson (1973).

\section{Data analysis}

In order to calculate the Germination (\%), Vigour Index (I and II), Root and Shoot length, Seedling Dry Weight and Root Shoot ratio, formula 1, formula 2 , formula 3 , formula 4 and formula 5 were used

\section{Germination (\%) \\ $=$ Number of normal seedlings $\times 100$ \\ Total seeds used for germination test}

V.I. (I) = Germination percentage (Normal seedling) X Seedling length $(\mathrm{cm})$

V.I. (II) $=$ Germination percentage (Normal seedling) X Dry weight of the seedling (gm)

Root and shoot length: Root and shoot length of five fresh seedlings was measured in centimetres up to one decimal. Total seedling length was calculated by adding root and shoot length.

Seedling dry weight: The seedlings used for recording were dried in an oven at $103^{\circ} \mathrm{C}+10 \mathrm{C}$ for 12 hours. Measurement of dried samples was record on an electronic balance upto three decimals in $\mathrm{mg}$.

\section{Results and Discussion}

The results of germination percentage as influenced by treated with different priming treatments during 2017-2018 and pooled data are presented in Table 1 and 2.

Perusal from table that significantly maximum increase in germination percentage occurs by $T_{2}$ [Osmopriming with poly ethylin glycol PEG 6000 (0.5 Mega Pascal) for $8 \mathrm{hrs}$ ] was $(94.50,95.41$ and $94.96 \%$ ) followed by $\mathrm{T}_{6}[$ Halopriming with $\mathrm{NaCl}$ (9\%) for $10 \mathrm{hrs}$ ] was $(93.99,94.10$ and $94.04 \%)$ while lowest germination percentage $(85.50,86.25$ and $85.88 \%$ ) was observed with unprimed control treatment during the year 2017-018 and in the pooled data, respectively. However, $\mathrm{T}_{1}, \mathrm{~T}_{6}, \mathrm{~T}_{7}, \mathrm{~T}_{9}$, $\mathrm{T}_{10}, \mathrm{~T}_{11}$ in first year while, $\mathrm{T}_{1}, \mathrm{~T}_{3}, \mathrm{~T}_{6}, \mathrm{~T}_{7}, \mathrm{~T}_{8}, \mathrm{~T}_{9}, \mathrm{~T}_{10}$ $\mathrm{T}_{11}$, in $2^{\text {nd }}$ year and $\mathrm{T}_{5}, \mathrm{~T}_{6}, \mathrm{~T}_{8}, \mathrm{~T}_{9}$ in pooled data found at par with $\mathrm{T}_{2}$ [Osmopriming with poly ethylin glycol PEG 6000 (0.5 Mega Pascal) for 8 hrs].

\section{Seedling length}

Perusal from table that significantly maximum increase in seedling length $(\mathrm{cm})$ occurs by $T_{2}$ [Osmopriming with poly ethylin glycol PEG 6000 (0.5 Mega Pascal) for $8 \mathrm{hrs}$ ] was $(37.88,37.72$ and $37.80 \mathrm{~cm}$ ) followed by $\mathrm{T}_{6}$ [Halopriming with $\mathrm{NaCl}$ (9\%) for $10 \mathrm{hrs}]$ was $(32.34,32.45$ and $32.39 \mathrm{~cm})$ while lowest seedling length $(\mathrm{cm})(13.16,14.66$ and 13.91) was observed with unprimed control treatment during the year 2017-018 and in the pooled data, respectively. However, $\mathrm{T}_{2}, \mathrm{~T}_{6}$ was found to be at par in first year while, $\mathrm{T}_{6}$, in $2^{\text {nd }}$ year and $\mathrm{T}_{6}$ in pooled data found at par with $\mathrm{T}_{2}$ [Osmopriming with poly ethylin glycol PEG 6000 (0.5 Mega Pascal) for $8 \mathrm{hrs}$ ].

\section{Seedling fresh weight (g)}

Perusal from table that significantly maximum increase in seedling fresh weight $(\mathrm{g})$ occurs by $\mathrm{T}_{2}$ [Osmopriming with poly ethylin glycol PEG 6000 (0.5 Mega Pascal) for $8 \mathrm{hrs}$ ] was $(6.60,6.71$ and 6.66) followed by $\mathrm{T}_{6}[$ Halopriming with $\mathrm{NaCl}(9 \%)$ for $10 \mathrm{hrs}$ ] was $(6.30,6.53$ and $6.41 \mathrm{~g})$ while lowest seedling fresh weight $(\mathrm{g})(5.11,4.84$ and $4.98 \mathrm{~g})$ was observed with unprimed control treatment during the year 2017-018 and in the pooled data, respectively. However, $\mathrm{T}_{1}, \mathrm{~T}_{6}, \mathrm{~T}_{7}, \mathrm{~T}_{9}, \mathrm{~T}_{10}, \mathrm{~T}_{11}$ in first year while, $T_{1}, T_{3}, T_{6}, T_{7}, T_{8}, T_{9}, T_{10} T_{11}$, in $2^{\text {nd }}$ year and $\mathrm{T}_{5}, \mathrm{~T}_{6}, \mathrm{~T}_{8}, \mathrm{~T}_{9}$ in pooled data found at par 
with $\mathrm{T}_{2}$ [Osmopriming with poly ethylin glycol PEG 6000 (0.5 Mega Pascal) for $8 \mathrm{hrs}$ ].

The results regarding root and shoot fresh and dry weights are in agreement with those of Ashraf and Rauf (2001) who reported that fresh and dry weights of seedlings from haloprimed seeds were significantly higher, as compared to other unprimed seeds. Seed priming may help in dormancy breakdown may be due to embryo development or leaching of emergence inhibitors (Yamauchi and Winn, 1996), which resulted in increased FEP these results are in agreement with Haigh and Barlow (1987) who found that $\mathrm{KNO}_{3}$ was beneficial in decreasing the emergence spread of tomato, carrot, onion and sorghum seeds.

\section{Seedling dry weight}

Perusal from table that significantly maximum increase in seedling dry weight $(\mathrm{g})$ occurs by $\mathrm{T}_{2}$ [Osmopriming with poly ethylin glycol PEG 6000 (0.5 Mega Pascal) for $8 \mathrm{hrs}$ ] was $(1.65,1.68$ and $1.66 \mathrm{~g}$ ) followed by $\mathrm{T}_{6}[$ Halopriming with $\mathrm{NaCl}$ (9\%) for $10 \mathrm{hrs}$ ] was $(1.58,1.60$ and $1.59 \mathrm{~g})$ while lowest seedling dry weight $(\mathrm{g})(1.28,1.21$ and $1.24 \mathrm{~g}$ ) was observed with unprimed control treatment during the year 2017-018 and in the pooled data, respectively. However, $\mathrm{T}_{6}, \mathrm{~T}_{8}, \mathrm{~T}_{9}$, was found to be at par with in first year while, $T_{6}$ in $2^{\text {nd }}$ year and $\mathrm{T}_{6}, \mathrm{~T}_{8}, \mathrm{~T}_{9}$ in pooled data found at par with $\mathrm{T}_{2}$ [Osmopriming with poly ethylin glycol PEG 6000 (0.5 Mega Pascal) for $8 \mathrm{hrs}$. The present results are in accordance with observation of Bennett and Waters (1987) who reported that seedling dry weight, seed germination and vigor in sweet corn decreased with osmo-conditioning, although germination significantly enhanced by water soaking. However, osmopriming has been shown to activate processes related to germination, for instance, by affecting the oxidative metabolic such as increasing superoxide dismutase (SOD) and peroxidase (POD) (Jie et al., 2002) or by the activation of ATPase as well as acid phosphatase and RNA syntheses (Fu et al., 1988).

\section{Seedling vigour index I}

Perusal from table that significantly maximum increase in vigour index-I occurs by $T_{2}$ [Osmopriming with poly ethylin glycol PEG 6000 (0.5 Mega Pascal) for 8 hrs] was (3579.70,
3598.9 and 3589.30) followed by $\mathrm{T}_{6}$ [Halopriming with $\mathrm{NaCl}(9 \%)$ for $10 \mathrm{hrs}$ ] was (3039.6, 3053.5 and 3046.6) while lowest vigour index-I (1125.2, 1264.4 and 1194.8) was observed with unprimed control treatment in the pooled data, during the year 2017-018 respectively. However, $\mathrm{T}_{3}, \mathrm{~T}_{4}, \mathrm{~T}_{6}, \mathrm{~T}_{9} \mathrm{~W}$ as found to be at par in first year while, $\mathrm{T}_{4}, \mathrm{~T}_{6}, \mathrm{~T}_{9}$ in $2^{\text {nd }}$ year and $\mathrm{T}_{4}, \mathrm{~T}_{6}, \mathrm{~T}_{9}$ in pooled data found at par with $\mathrm{T}_{2}$ [Osmopriming with poly ethylin glycol PEG 6000 (0.5 Mega Pascal) for 8 hrs].

Perusal from table that significantly maximum increase in vigour index-II occurs by $T_{2}$ [Osmopriming with poly ethylin glycol PEG 6000 (0.5 Mega Pascal) for $8 \mathrm{hrs}$ ] was (155.93, 160.29 and 158.11 ) followed by $\mathrm{T}_{6}[$ Halopriming with $\mathrm{NaCl}(9 \%)$ for $10 \mathrm{hrs}$ ] was $(148.50,142.09$ and 145.30) while lowest vigour index-II (109.44, 104.36 and 106.90) was observed with unprimed control treatment in the pooled data during the year 2017-018, respectively. However, $\mathrm{T}_{3}$ [Osmopriming with poly ethylin glycol PEG 6000 (0.5 Mega Pascal) for 10 hrs] to $\mathrm{T}_{9}$ [Magnetic priming (75Mili Tesla for 5minutes] was found to be at par in first year while, $\mathrm{T}_{1}, \mathrm{~T}_{3}, \mathrm{~T}_{6}, \mathrm{~T}_{7}, \mathrm{~T}_{8}, \mathrm{~T}_{9}, \mathrm{~T}_{10}$ in $2^{\text {nd }}$ year and $\mathrm{T}_{1}, \mathrm{~T}_{6}, \mathrm{~T}_{7}, \mathrm{~T}_{9}, \mathrm{~T}_{11}$ in pooled data found at par with $\mathrm{T}_{2}$ [Osmopriming with poly ethylin glycol PEG 6000 (0.5 Mega Pascal) for 8 hrs].

Priming with PEG and $\mathrm{NaCl}$, significantly improved MGR and SVI. Comparison of seedling vigor index means of seeds exposed to priming in the PEG and $\mathrm{NaCl}$ solutions. Liu et al. (1996) have found that osmopriming improves both germination rate and speed in tomato seeds, especially when they utilized freshly harvested seeds. Our data confirmed that the primed seed with PEG-6000 or $\mathrm{NaCl}$ solution is a simple and effective way to improve all seed characteristics investigated, compared to those of the control treatment. These are similar finding results reported by Pallais (2006), Venkatasubramanian and Umarani (2007), Mohamed and Hannachi (2012). 
Table.1 Mean performance of seedling characters of Chickpea Desi (DCP-92-3-3)

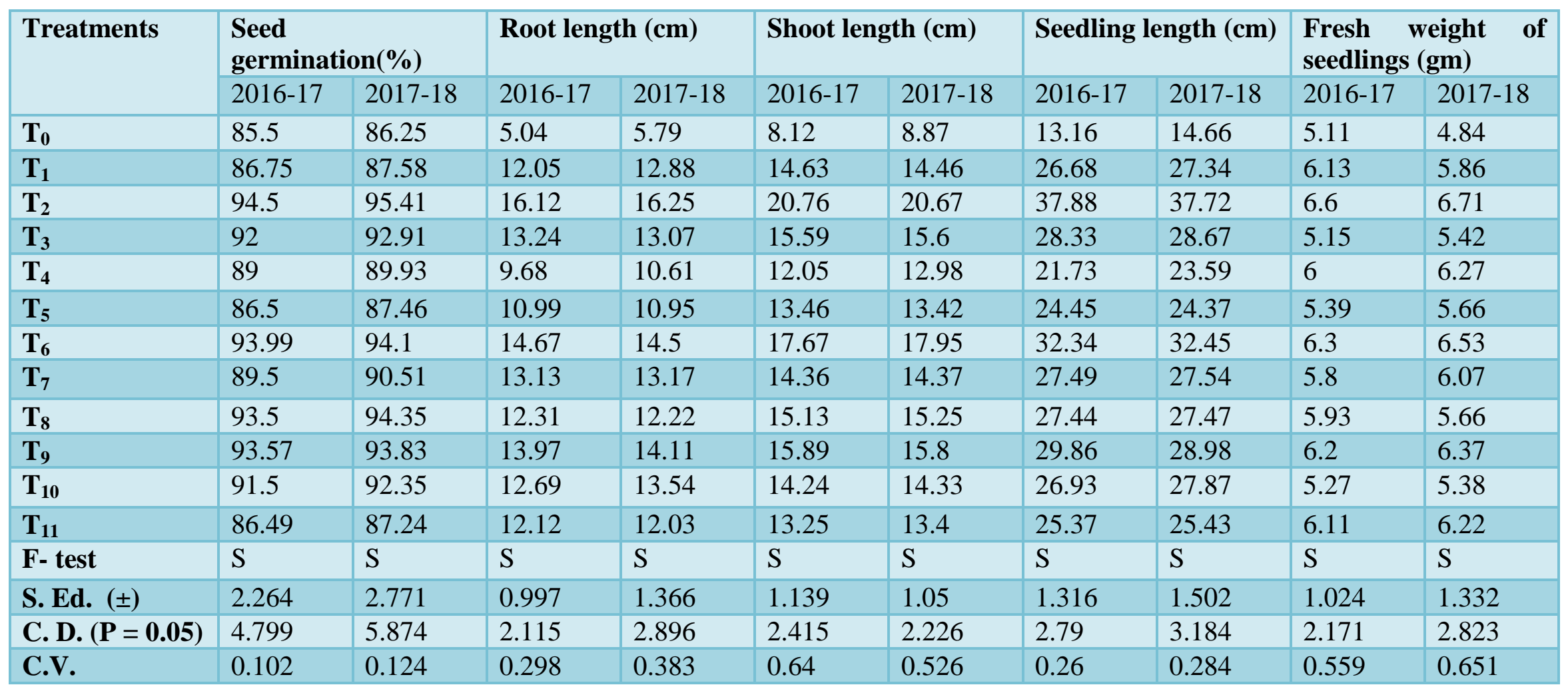

Legends: $\mathrm{T}_{0}-$ Control, $\mathrm{T}_{1}$ - Hydro priming (HP) with distilled water $12 \mathrm{hrs}, \mathrm{T}_{2}$ - Osmopriming with poly ethylin glycol PEG 6000 ( $0.5 \mathrm{Mega}$ Pascal) for 8 hrs , $\mathrm{T}_{3}$ - Osmopriming with poly ethylin glycol PEG 6000 ( $0.5 \mathrm{Mega}$ Pascal) for $10 \mathrm{hrs}, \mathrm{T}_{4}$. Osmopriming with poly ethylin glycol PEG 6000 (0.5 Mega Pascal) for $12 \mathrm{hrs}, \mathrm{T}_{5}$. Halopriming with $\mathrm{NaCl}(9 \%)$ for $8 \mathrm{hrs}, \mathrm{T}_{6}$. Halopriming with $\mathrm{NaCl}(9 \%)$ for $10 \mathrm{hrs}, \mathrm{T}_{7}$. Halopriming with $\mathrm{NaCl}(9 \%)$ for $12 \mathrm{hrs}, \mathrm{T}_{8}$. Magnetic priming (50Mili Tesla for 5 minutes), $\mathrm{T}_{9}$. Magnetic priming (75Mili Tesla for 5 minutes), $\mathrm{T}_{10}$ - Electric priming (0.5 Ampere for 5 minutes), $\mathrm{T}_{11}$. Electric priming (1.0 Ampere for 5 minutes), F- test, S. Ed. ( \pm ) - Standard Error of difference ( \pm ),C. D. (P = 0.05) - Critical Difference, C.V.- Coefficient of variation (\%)Percentage, $(\mathrm{cm})$ - Centimeter, gm- Gram ,ISTA -International Seed Testing Association 
Table.2 Mean performance of seedling characters of Chickpea Desi (DCP-92-3-3)

\begin{tabular}{|c|c|c|c|c|c|c|c|c|}
\hline \multirow[t]{2}{*}{ Treatments } & \multicolumn{2}{|c|}{$\begin{array}{l}\text { Dry weight of } \\
\text { seedlings(gm) }\end{array}$} & \multicolumn{2}{|c|}{ Vigour index I } & \multicolumn{2}{|c|}{ Vigour index II } & \multicolumn{2}{|c|}{ Root shoots Ratio } \\
\hline & 2016-17 & 2017-18 & 2016-17 & $2017-18$ & $2016-17$ & $2017-18$ & 2016-17 & 2017-18 \\
\hline $\mathbf{T}_{\mathbf{0}}$ & 1.28 & 1.21 & 1125.2 & 1264.4 & 109.44 & 104.36 & 0.62 & 0.65 \\
\hline $\mathbf{T}_{1}$ & 1.53 & 1.47 & 2314.5 & 2394.4 & 132.73 & 128.74 & 0.82 & 0.89 \\
\hline $\mathbf{T}_{2}$ & 1.65 & 1.68 & 3579.7 & 3598.9 & 155.93 & 160.29 & 0.82 & 0.82 \\
\hline $\mathbf{T}_{\mathbf{3}}$ & 1.29 & 1.36 & 2652.4 & 2663.7 & 118.68 & 126.36 & 0.85 & 0.84 \\
\hline $\mathbf{T}_{4}$ & 1.5 & 1.51 & 1934 & 2121.4 & 133.5 & 141.19 & 0.8 & 0.82 \\
\hline $\mathbf{T}_{5}$ & 1.35 & 1.42 & 2114.9 & 2131.4 & 116.78 & 124.19 & 0.82 & 0.82 \\
\hline $\mathbf{T}_{6}$ & 1.58 & 1.6 & 3039.6 & 3053.5 & 148.5 & 142.09 & 0.83 & 0.81 \\
\hline $\mathbf{T}_{7}$ & 1.45 & 1.52 & 2460.4 & 2492.6 & 129.78 & 137.58 & 0.91 & 0.94 \\
\hline $\mathbf{T}_{8}$ & 1.48 & 1.42 & 2565.6 & 2591.8 & 138.38 & 133.98 & 0.81 & 0.8 \\
\hline $\mathbf{T}_{9}$ & 1.55 & 1.59 & 2794 & 2719.2 & 145.03 & 149.19 & 0.88 & 0.83 \\
\hline $\mathbf{T}_{10}$ & 1.32 & 1.35 & 2464.1 & 2573.8 & 120.78 & 124.67 & 0.89 & 0.92 \\
\hline $\mathbf{T}_{11}$ & 1.52 & 1.56 & 2194.3 & 2218.5 & 132.33 & 136.09 & 0.91 & 0.9 \\
\hline F- test & $\mathrm{S}$ & $\mathrm{S}$ & $\mathrm{S}$ & $S$ & $\mathrm{~S}$ & S & S & $\mathrm{S}$ \\
\hline S. Ed. $( \pm)$ & 0.618 & 0.624 & 125.87 & 149.472 & 50.612 & 51.508 & 0.618 & 0.624 \\
\hline C. D. $(P=0.05)$ & 1.31 & 1.323 & 266.845 & 316.88 & 107.297 & 109.198 & 1.31 & 1.323 \\
\hline C.V. & 0.713 & 0.576 & 0.274 & 0.308 & 0.639 & 0.516 & 0.713 & 0.576 \\
\hline
\end{tabular}

Legends: $\mathrm{T}_{0}$ - Control, $\mathrm{T}_{1}$ - Hydro priming (HP) with distilled water $12 \mathrm{hrs}, \mathrm{T}_{2}$ - Osmopriming with poly ethylin glycol PEG 6000 (0.5 Mega Pascal) for $8 \mathrm{hrs}, \mathrm{T}_{3}$. Osmopriming with poly ethylin glycol PEG 6000 ( $0.5 \mathrm{Mega}$ Pascal) for $10 \mathrm{hrs}, \mathrm{T}_{4}$. Osmopriming with poly ethylin glycol PEG 6000 (0.5 Mega Pascal) for 12 hrs, $\mathrm{T}_{5}$. Halopriming with $\mathrm{NaCl}(9 \%)$ for $8 \mathrm{hrs}, \mathrm{T}_{6}$. Halopriming with $\mathrm{NaCl}(9 \%)$ for $10 \mathrm{hrs}, \mathrm{T}_{7} . \mathrm{Halopriming}$ with $\mathrm{NaCl}(9 \%)$ for $12 \mathrm{hrs}, \mathrm{T}_{8}$. Magnetic priming (50Mili Tesla for 5minutes), $\mathrm{T}_{9}$. Magnetic priming (75Mili Tesla for 5minutes), $\mathrm{T}_{10}$ - Electric priming (0.5 Ampere for 5 minutes), $\mathrm{T}_{11}$ - Electric priming (1.0 Ampere for minutes), F- test, $\mathrm{S}$. Ed. $( \pm)$ - Standard Error of difference ( \pm ), C. D. $(\mathrm{P}=0.05)$ - Critical Difference, C.V.- Coefficient of variation (\%)-Percentage, $(\mathrm{cm})$ - Centimeter, g- Gram 
On the basis of result obtained from the present experiment, following conclusions are drawn. Among all the seed priming treatments, seed priming with PEG 6000 (osmo priming) was found to be the best priming treatment followed by organic priming. Among all seed priming treatments PEG 2\% having more pronounced effect on germination behavior and vigour in kabuli chickpea seeds.

\section{Root shoot ratio}

Perusal from table that significantly maximum increase in root shoot ratio occurs by $\mathrm{T}_{7}$ [Halopriming with $\mathrm{NaCl}(9 \%)$ for 12 hrs] was (0.91, 0.94 and 0.93), while lowest root shoot ratio $(0.62,0.65$ and 0.64$)$ was observed with unprimed control treatment during the year 2017-018 and in the pooled data, respectively. However, $\mathrm{T}_{1}, \mathrm{~T}_{6}, \mathrm{~T}_{7}, \mathrm{~T}_{9}, \mathrm{~T}_{10}$, $\mathrm{T}_{11}$ in first year while, $\mathrm{T}_{1}, \mathrm{~T}_{3}, \mathrm{~T}_{6}, \mathrm{~T}_{7}, \mathrm{~T}_{8}, \mathrm{~T}_{9}, \mathrm{~T}_{10}$ $\mathrm{T}_{11}$, in $2^{\text {nd }}$ year and $\mathrm{T}_{5}, \mathrm{~T}_{6}, \mathrm{~T}_{8}, \mathrm{~T}_{9}$ in pooled data found at par with $\mathrm{T}_{2}$ [Osmopriming with poly ethylin glycol PEG 6000 (0.5 Mega Pascal) for $8 \mathrm{hrs}$ ].

Seed primed in $\mathrm{NaCl}$ solution and distilled water had the lngest radical and plumule compared to the other primers. Seeds were treated with halo-priming with $\mathrm{NaCl}$ solution could improved seed germination under freestress condition and also alleviated effects of salinity and drought stresses on seedling growth. However, mean comparison of seedling fresh and dry weight showed that hydro primed seed produced the maximum seedling weight followed by $\mathrm{NaCl}$.

Considering the above findings achieved from the present study it may be concluded that osmopriming has a positive significant effect on germination, seedling growth and water relation behavior on wheat seed under salt stress condition. The germination, seedling growth and water relation behavior of Chickpea seeds decreased with increasing of salt concentrations but the decrease was gradually slow. This might be due to the osmoprimed agent (PEG) which triggers the germination, seedling growth and water relation behavior of wheat genotypes though under salt stress conditions. So, it can be concluded that priming helps to improve the germination, seedling growth and water relation behaviors of Chickpea seeds under salt stress condition

Chickpea DCP-92-3 seeds were treated with PEG $6000(0.5 \%)$ for 8 hours showed better germination and vigour traits of the treated seed samples showed better performance when compared to untreated ones as they were treated with $\mathrm{NaCl}(9 \%)$ for 10 hours.

During storage period, germination, viability, seed moisture and health status of the seeds depends upon packaging materials, duration and environmental conditions where plastic bags [700 gauge] can be used for maintaining the shelf-life of seeds during storage period at [8\%] moisture level.

The results also indicates that the application of magnetic seed treatments with $75 \mathrm{mT}$ [militesla] for 5 minutes duration can be an eco-friendly practice that improves plant characteristics in all the stages, from germination to final yield. This study should give a better understanding of the response of seeds to electric fields.

\section{Acknowledgments:}

The authors are grateful to the Indian Institute of Pulses Research (IIPR), Kanpur, Uttar Pradesh for providing desi (DCP-92-3) of Chickpea seeds. Sincere thanks to all the faculty members of the Department for their encouragement and support. Thanks are also due to the Head, Department of Genetics and Plant Breeding, SHUATS, Prayagraj, for providing the necessary facilities. 


\section{References}

Abdul-Baki, A.A. and Anderson, J.D. (1973). Vigour determination in soybean seeds by multiple criteria. Crop Science, 13: 630-633.

Ashraf, M. and Rauf, H. (2001) Inducing Salt Tolerance in Maize (Zea mays L.) through Seed Priming with Chloride Salts: Growth and Ion Transport at Early Growth Stages. Acta Physiology Plantarum, 23, 407-414.

Bennett, M.A. and L. Waters, Jr., 1987. Seed hydration treatments for improved sweet maize germination and stand establishment. J. Amer. Soc. Hort. Sci., 112: 45-49.

Fu, K. S., R. C. González and C. S. Lee (1988). Robotics: Control, sensing, vision and Intelligence. New York: McGraw Hill.

Haigh, A.M. Barlow, E.W.R. Journal of the American Society for Horticultural Science (USA): 112 (3): 202-208.

International Seed Testing Association (2010). International Rules for Seed Testing: edition 2010. ISTA, Bassersdorf, Switzerland.

Jie LL, Ong S, Dong MO, Fang L, Hua EW (2002). Effect of PEG on germination and active oxygen metabolism in wild rye (Leymus chinensis) seeds. Acta Prat. Sin, 11: 59-64.

Lemrasky MG, Hosseini SZ (2012). Effect of seed priming on the germination behavior of wheat. Int J Agric Crop Sci
4: $564-567$

Liu H (1996) Saccharomyces cerevisiae S288C has a mutation in FLO8, a gene required for filamentous growth. Genetics 144(3):967-978.

Pirasteh, A. H., Sdeghi,h and Emam, Y. (2011) Chemical priming with urea and $\mathrm{NaCl}$ enhances maize (Zea mays L.) hybrid seed viability under aboitic stress. Journal of Crop Science and Biotechnology, 14 :289-295

Rai PK, Kumar G and Singh KK (2011). Influence of packaging material and storage time on seed germination and chromosome biology of inbred line of maize (Zea mays L.). Journal of Agricultural Technology, 7(6): 17651774.

Rostami Zadeh E., Majd A., Arbabian S (2014). Effects of Electromagnetic Fields on Seed Germination In Urtica dioica L. International Journal of Scientific and Technology Research, 3(4): 365-368.

Yamauchi, M. and T. Winn, 1996. Rice seed vigor and seedling establishment in anaerobic soil. Crop Science, 36: 680690.

Yanjun Zhao, Jing Liu, Haifeng Qin, Zhenhai Liang (2012) The Effect of Electrochemical Processing on Biological Behavior of Wheat Seeds Germination. International Journal of Electrochemical Science, 7: 11313 11322 .

\section{How to cite this article:}

Rupesh Kumar and Prashant Kumar Rai. 2020. Pre Sowing Seed Treatments Of Magnetic, Electric, Polyethylene Glycol, Sodium Chloride On Seedling Parameters of Desi Chickpea (Cicer Arietinum L.). Int.J.Curr.Microbiol.App.Sci. 9(01): 1339-1346.

doi: https://doi.org/10.20546/ijcmas.2020.901.148 